\title{
IDENTIFIKASI RHODAMIN B PADA SAGU MUTIARA DI PASAR INDUK KOTA BANDUNG TAHUN 2019
}

\author{
Tantan Widiantara, Hasnelly, Zachra Satira \\ Program Studi Teknologi Pangan, Fakultas Teknik, Universitas Pasundan, Jl. Dr. Setiabudhi No.193, Bandung, 40153, \\ Indonesia \\ E-mail : tantanwidiantara@unpas.ac.id
}

\begin{abstract}
Abstrak
Sagu mutiara merupakan hasil olahan pati sagu yang berbentuk butiran(bulat-bulat) dengan warna merah, putih atau hijau. Warna pada sagu mutiara yang umum dijual tersebut sering kali terang dan mencurigakan. Penggunaan bahan tambahan pangan berbahaya masih marak terjadi karena ketidaktahuan masyarakat terhadap hal ini, terutama dalam hal penggunaan zat pewarna sintetik berbahaya rhodamin B, sehingga tujuan penelitian ini adalah untuk mengetahui ada atau tidaknya penambahan rhodamin B pada sagu mutiara di Pasar Induk Kota Bandung dan untuk mengetahui jumlah kontaminasi rhodamin B pada sagu mutiara yang dijual di Pasar Induk Kota Bandung. Pasar Induk dipilih sebagai tempat penelitian karena merupakan pasar terbesar yang biasanya menyalurkan berbagai kebutuhan kepada pasar lain disekitarnya. Metode penelitian yang digunakan adalah metode purposive sampling dengan mengambil seluruh populasi untuk dijadikan sampel sehingga menghasilkan 13 sampel terpilih dari 12 pedagang. Sebanyak 4 sampel didapatkan dari Pasar Induk Gede Bage dan 9 sampel dari 12 pedagang didapatkan dari Pasar Induk Caringin. Analisis kualitatif zat pewarna dilakukan dengan metode spot test. Sedangkan analisis kuantitatif dilakukan dengan metode spektrofotometri. Hasil penelitian secara kualitatif menunjukkan bahwa sagu mutiara tidak mengandung rhodamin B, namun teridentifikasi pewarna jenis lain yaitu crystal panceau, amaranth dan azorubin A, sehingga tidak dilakukan analisis lebih lanjut secara kuantitatif. Crystal panceau dan Amaranth merupakan bahan pewarna yang dilarang sedangkan azorubin A atau karmoisin merupakan bahan pewarna yang diperbolehkan dalam batas tertentu. Sampel yang teridentifikasi sebagai produk yang mengandung pewarna crystal panceau sebanyak 10 sampel, sedangkan sampel yang teridentifikasi mengandung pewarna amaranth dan azorubin A masing-masing sebanyak satu sampel, lalu satu sampel lainnya tidak teridentifikasi jenis pewarnanya
\end{abstract}

\begin{abstract}
Pearl sago is the result of processed sago starch in the form of granules (rounded) with red, white or green. The color of the commonly sold pearl sago is often bright and suspicious. The use of hazardous food additives is still rife due to the community's ignorance of this matter, especially in the case of the use of dangerous synthetic dyes rhodamin B, so the purpose of this study is to determine whether or not the addition of rhodamin B in pearl sago in Bandung Central Market and to find out the amount of rhodamin B contamination in pearl sago sold at the Bandung City Main Market. The Central Market was chosen as a place of research because it is the largest market that usually supplies a variety of needs to other markets around it. The research method used was purposive sampling method by taking the entire population to be sampled to produce 13 selected samples from 12 traders. A total of 4 samples were obtained from the Gede Bage Central Market and 9 samples from 12 traders were obtained from the Caringin Central Market. Qualitative analysis of dyes was carried out by the spot test method. Whereas quantitative analysis was carried out using the spectrophotometric method. The results of the study qualitatively showed that pearl sago did not contain rhodamine B, but other types of dyes were identified namely crystal panceau, amaranth and azorubin A, so no further quantitative analysis was performed. Panceau and Amaranth crystals are prohibited coloring agents, while azorubin A or karmoisin are allowed to a certain extent. Samples identified as products containing panceau crystal dyes were 10 samples, while the identified samples contained amaranth and azorubin A dyes one sample each, then one other sample did not identify the type of coloring.
\end{abstract}

Keywords: Sago, pearl sago, coloring, spot test

\section{Pendahuluan}

Penentuan bahan makanan pada umumnya sangat berpengaruh pada beberapa faktor di antaranya citarasa, warna, tekstur, dan nilai gizinya; disamping itu ada faktor lain, misalnya sifat mikrobiologis. Tetapi sebelum faktor-faktor lain dipertimbangkan, secara visual faktor warna tampil lebih dahulu dan kadang- kadang sangat menentukan (Winarno dalam Nur'aini dan Apriyani, 2015).

Pewarna tambahan makanan umum digunakan oleh masyarakat baik itu pewarna alami maupun sintetis. Pewarna alami biasanya aman digunakan pada makanan atau tidak akan menimbulkan resiko kesehatan, contoh pewarna alami yang sering digunakan yaitu daun suji 
untuk memberi warna hijau, kunyit untuk memberi warna kuning, dan cabai untuk memberi warna merah.

Pewarna sintetis memiliki jenis yang aman digunakan dalam batas yang telah ditentukan dan ada pula yang tidak aman digunakan atau dapat menimbulkan resiko kesehatan sehingga tidak boleh digunakan sama sekali. Contoh pewarna sintetis yang aman digunakan menurut permenkes nomor 033 tahun 2012 yaitu Kuning kuinolin CI. No. 47005 Quinoline yellow, Merah allura CI. No. 16035 (Allura red) dan Hijau FCF CI. No. 42053 (Fast green FCF). Lalu contoh pewarna sintetis yang tidak aman digunakan yaitu, Fast Yellow AB, Guinea Green B, dan rhodamin B (Permenkes RI No. 239/Menkes/Per/V/1985).

Sering sekali terjadi penyalahgunaan pemakaian zat pewarna tersebut antara lain disebabkan oleh ketidaktahuan masyarakat mengenai zat pewarna untuk pangan, dan juga karena harga zat pewarna untuk industri relatif jauh lebih murah dibandingkan dengan zat pewarna untuk pangan (Andayani dan Adisaputra, 2013).

Kasus yang paling sering ditemui tentang penyalahgunaan pewarna sintetis yang dilarang adalah penggunaan pewarna rhodamin B. Rhodamin B merupakan pewarna sintetis yang menghasilkan warna kemerahan dan seharusnya digunakan untuk pewarna tekstil. Dalam masyarakat, rhodamin B biasa digunakan pada produk pangan olahan seperti kue, saus, kerupuk, terasi, sirup, makanan ringan, dll.

Ciri-ciri pangan yang mengandung rhodamin B antara lain warnanya cerah mengkilap dan lebih mencolok, terkadang warna terlihat tidak rata, ada gumpalan warna pada produk, dan bila dikonsumsi rasanya sedikit lebih pahit. Biasanya produk pangan yang mengandung zat ini tidak mencantumkan kode, label, merek, atau identitas lengkap lainnya (Nurrohmah, 2018).

Dampak kesehatan yang dapat terjadi jika mengonsumsi rhodamin B dalam jangka panjang antara lain iritasi saluran pernafasan, kulit, mata, saluran pencernaan, keracunan dan gangguan hati, serta dalam jangka panjang kanker dan tumor (Tjiptaningdyah dan Sucahyo, 2017).

Namun mayoritas masyarakat saat ini masih tidak mengetahui tentang resiko kesehatan tersebut, sehingga penggunaan rhodamin B masih marak terjadi. Akibatnya, konsumen dapat menjadi korban atas kecurangan yang dilakukan oleh produsen demi tetap dapat menjual produknya dengan harga terjangkau.

Upaya terus-menerus dari pemerintah dalam mensosialisasikan dampak buruk kesehatan dari penggunaan zat pewarna berbahaya harus terus dilakukan, juga penelitian lebih lanjut mengenai makanan ataupun minuman yang mungkin disinyalir menggunakan bahan berbahaya tersebut dari para peneliti. Dimana dalam hal ini penulis memilih sagu mutiara untuk diteliti.
Sagu mutiara adalah produk olahan pangan dengan bahan baku utama tepung pati. Sagu mutiara merupakan produk diversifikasi akibat pesatnya perkembangan industri pati(starch) di indonesia. Pati yang digunakan untuk sagu mutiara berasal dari tanaman sagu ataupun ubi kayu.

Ubi kayu merupakan bahan pangan sumber karbohidrat pengganti beras yang peranannya cukup penting di Indonesia,. Perkembangan produktivitas ubikayu di Indonesia selama 1980-2016 cenderung mengalami peningkatan, laju pertumbuhan rata-rata meningkat sebesar $2,64 \%$ per tahun (Widaningsih, 2016).

Ubi kayu (Manihot esculenta Crantz) memiliki fungsi sebagai salah satu tempat penyimpanan pati pada bagian akar dan merupakan bahan yang potensial bagi masa depan dalam tatanan pengembangan agribisnis dan agroindustri (Augustyn, 2007). Selain ubi kayu, pati juga dapat ditemukan pada tanaman sagu.

Tanaman sagu juga merupakan sumber karbohidrat lain selain beras dan umbi-umbian. Sagu memegang peranan penting dalam penganekaragaman makanan untuk menunjang stabilitas pangan. Tanaman sagu memiliki berpotensi untuk dikembangkan dan dimanfaatkan di Indonesia (Elida dan Vaulina, 2015).

Direktorat jenderal perkebunan menyebutkan Indonesia memproduksi sebanyak 470,883 ton sagu pada tahun 2018 dan diperkirakan akan meningkat hingga 478,361 ton pada tahun 2019. Potensi sagu yang tersedia mendorong tumbuhnya industri sagu dan olahannya. Diversifikasi pangan pada pati sagu antara lain mie, kerupuk, kue, sagu mutiara, dll.

Sagu mutiara merupakan produk pangan yang biasa digunakan untuk campuran kue, atau sebagai campuran makanan seperti es campur dan sekoteng. Di kalanagan masyarakat, sagu mutiara dikenal dengan sebutan sekoteng, pacar cina, ataupun biji delima. Umumnya sagu mutiara berbentuk butiran dengan warna merah, putih atau hijau. Warna pada sagu mutiara yang umum dijual tersebut sering kali terang dan mencurigakan.

Bahan tambahan pangan berbahaya masih marak penggunaannya karena ketidaktahuan masyarakat terhadap hal ini. Sehingga umumnya tindak kecurangan pada bahan pangan terjadi di pasar tradisional yang lebih bebas dalam memperjual-belikan apapun karena pengawasan yang tidak ketat seperti di pasar swalayan. Kemudian pasar induk yang merupakan pasar penyalur segala kebutuhan untuk pasar lainnya bisa dianggap sebagai pasar acuan, sehingga penulis memilih pasar induk sebagai tempat penelitian.

\section{Bahan dan Metode Penelitian}

Bahan-bahan yang digunakan untuk penelitian analisis kandungan rhodamin B pada sagu mutiara adalah sampel sagu mutiara yang diperoleh dari pasar induk terpilih di Kota Bandung. Kemudian sampel sagu mutiara dibawa ke Laboratorium Penelitian Teknologi Pangan Universitas Pasundan. 
Bahan kimia yang digunakan untuk analisis kandungan rhodamin B secara kualitatif pada sagu mutiara adalah HCL $6 \mathrm{~N}$, HCL pekat, $\mathrm{H} 2 \mathrm{SO} 4$ pekat, $\mathrm{NH} 4 \mathrm{OH} 10 \%$, aquadest, dan $\mathrm{NaOH} 30 \%$ yang diperoleh dari Laboratorium Penelitian Teknologi Pangan Universitas Pasundan.

Alat-alat yang digunakan untuk analisis kandungan rhodamin B secara kualitatif pada sagu mutiara adalah pipet berukuran, wol, pipet tetes, gelas kimia, plat tetes, kawat kassa, kompor, pinset, filler, spatula, kertas label, dan pulpen.

Bahan kimia yang digunakan untuk analisis kandungan rhodamin B secara kuantitatif pada sagu mutiara adalah larutan 2\% ammonia dalam $70 \%$ alkohol, natrium hidroksida $10 \%$, natrium hidroksida $5 \%$, dan HCL 0,1N yang diperoleh dari Laboratorium Penelitian Teknologi Pangan Universitas Pasundan.

Alat-alat yang digunakan untuk analisis kandungan rhodamin B secara kualitatif pada sagu mutiara adalah timbangan, neraca digital, gelas kimia, kertas saring, corong, labu erlenmeyer, labu ukur, kuvet, pipet tetes, pipet mikron dan spektrofotometer UV-Vis.

Metode penelitian yang digunakan yaitu penelitian deskriptif, yang bertujuan untuk mengetahui nilai masing-masing variabel, yang sifatnya independen tanpa membuat hubungan maupun perbandingan dengan variabel lain (Sujarweni, 2014).

Penelitian ini meliputi beberapa tahap yaitu : penentuan tempat penelitian, survey lapangan, penentuan jumlah sampel dan pengambilan sampel, pengujian sampel serta pengolahan data.

\section{Tahap 1. Penentuan Tempat Penelitian}

Penentuan tempat penelitian dilakukan berdasarkan data jumlah pasar dan statistik pedagang pasar di Kota Bandung yang diperoleh dari literatur, serta pertimbangan dari metode sampling yang akan digunakan, dimana dalam hal ini purposive sampling adalah metode yang dipilih.

Berdasarkan data statistik serta pendekatan metode purposive sampling, tempat penelitian yang terpilih adalah Pasar Induk sebagai pasar pusat dan yang terbesar di Kota Bandung, sehingga diharapkan dapat mewakili pasar-pasar yang berada disekitarnya. Pasar yang termasuk kategori Pasar Induk di Kota Bandung yaitu Pasar Induk Gede Bage dan Pasar Induk Caringin.

\section{Tahap 2. Survey Lapangan}

Survey lapangan dilakukan dengan mengunjungi secara langsung pasar yang terpilih, dan mengobservasi setiap pedagang pasar.

\section{Tahap 3. Penentuan Jumlah Sampel dan Pengambilan Sampel}

Penentuan jumlah sampel yang harus diambil dilakukan menggunakan persamaan Slovin dengan menetapkan presisi yang akan diambil berkisar 5\%, $10 \%$ atau $15 \%$. Presisi ditetapkan untuk memperkecil terjadinya eror, sehinngga sampel yang diambil diharapkan dapat mewakili untuk seluruh Pasar Induk di Kota Bandung.

Sampling dilakukan terhadap sagu mutiara dimana populasi dipilih dari pedagang bahan kue di pasar induk di Kota Bandung. Kemudian peneliti menentukan jumlah sampel yang diambil dari populasi Pasar Induk di Kota Bandung dengan menggunakan persamaan slovin. Persamaan Slovin (Bungin, 2005) adalah sebagai berikut.

$$
n=\frac{N}{N(d)^{2}+1}
$$

Keterangan :

$\mathrm{n} \quad=$ Jumlah sampel yang dicari

= Jumlah populasi

$=$ Nilai presisi

Pengambilan sampel sendiri akan dilakukan di Pasar Induk di Kota Bandung yang disertai dengan sesi wawancara kepada para pedagang. Kemudian sampel sagu mutiara dibawa ke Laboratorium Penelitian Teknologi Pangan Universitas Pasundan. Setelah sampel didapatkan, selanjutnya sampel dan bahan uji lainnya akan disiapkan untuk pengujian rhodamin B secara kualitatif dan kuantitatif.

\section{Tahap 4. Pengujian Sampel}

Pengujian kualitatif yang dilakukan menggunakan metode spot test. Prinsip metode ini adalah berdasarkan reaksi pengasaman dengan $\mathrm{HCl}$, adanya zat warna akan nampak pada sampel yang berwarna. Zat warna alami akan menghilang dalam pencucian sedangkan zat warna sintetis tidak. Selanjutnya akan dilakukan penentuan jenis pewarna sintetis yang digunakan dengan metode reaksi kimia, kemudian hasilnya akan dicocokkan dengan tabel. Jika sampel positif mengandung rhodamin $\mathrm{B}$, akan dilakukan pengujian secara kuantitatif.

Pengujian secara kuantitatif yang digunakan adalah metode spektrofotometri Uv-Vis, dengan prinsip berdasarkan penyerapan cahaya polikromatis yang diubah menjadi cahaya monokromatis yang sesuai dengan hukum Beer, yang menyatakan bahwa "Bila suatu cahaya monokromatis mengenai medium transparan (berwarna) maka bertambah intensitas cahaya yang dipancarkan sebanding dengan tebalnya kepekaan dari media adsorpsi." Absorben sampel yang terukur merupakan cahaya yang diteruskan oleh fototube dan diubah menjadi energi listrik yang terukir pada panjang gelombang tertentu.

\section{Tahap 5. Pengolahan Data}

Hasil analisis akan di rekap menggunakan tabel agar memudahkan dalam pengambilan kesimpulan. Data hasil analisispun akan diubah dalam bentuk presentase sehingga dapat diketahui berapa banyak sampel sagu mutiara yang tercemar bahan pewarna berbahaya rhodamin $\mathrm{B}$. 


\section{Hasil dan Pembahasan}

\section{Hasil Analisis Rhodamin B}

Pasar tradisional yang terdapat di Kota Bandung berjumlah 41 pasar dengan total jumlah pedagang yang tercatat yaitu sebanyak 27.633 pedagang, sehingga untuk penelitian perlu diperkecil area penelitiannya untuk mempermudah dalam melakukan penelitian. Sehingga pada Tahap 1, pasar yang dipilih sebagai tempat penelitian yaitu pasar induk Kota Bandung yang dianggap sebagai pasar pusat atau pasar terbesar yang biasanya memasok pasar-pasar lainnya di Kota Bandung.

Kota Bandung memiliki dua pasar induk yaitu Pasar Induk Gede Bage dan Pasar Induk Caringin. Dalam hasil survey lapangan pada tahap 2 penelitian, terdapat 4 pedagang yang menjual produk sagu mutiara di Pasar Induk Gede Bage dan 8 pedagang di Pasar Induk Caringin.

Sampel yang dipilih sebagai objek penelitian pada tahap 3 diambil dari $100 \%$ total populasi yaitu sebanyak 12 pedagang sehingga perhitungan rumus slovin tidak digunakan. Hal ini dikarenakan jumlah populasi dilapangan yang terhitung sedikit sehingga harus digunakan seluruhnya agar representatif.

Sampel yang digunakan dalam penelitian tidak bermerk sama, dengan total keseluruhan berjumlah 13 sampel, 4 diantaranya dan dari Pasar Induk Gede Bage, dengan 1 produk berjenis sagu mutiara basah sedangkan 3 lainnya adalah produk sagu mutiara kering. Sedangkan dari Pasar Induk Caringin terdapat 9 sampel dari 8 pedagang, 4 diantaranya berjenis sagu mutiara basah dan 5 produk berjenis sagu mutiara kering.

Setelah penentuan jumlah sampel dan pengambilan sampel pada tahap 3, tahap berikutnya adalah tahap 4 dan 5, yaitu pengujian sampel dan pengolahan data. Pada saat pengujian di laboratorium, sampel akan dianalisis secara kualitatif terlebih dahulu, jika terdapat sampel yang positif, selanjutnya akan dilakukan pengujian secara kuantitatif. Berikut adalah hasil analisis zat pewarna secara kualitatif yang dapat dilihat di Tabel 1.

Tabel 1. Hasil Analisis Kualitatif Rhodamin B

\begin{tabular}{|c|c|c|c|c|}
\hline No. & $\begin{array}{l}\text { Nama } \\
\text { Pasar }\end{array}$ & $\begin{array}{l}\text { Kode } \\
\text { Sampel }\end{array}$ & Hasil & $\begin{array}{l}\text { Jenis Pewarna } \\
\text { Teridentifikasi }\end{array}$ \\
\hline 1. & $\begin{array}{l}\text { Pasar } \\
\text { Induk } \\
\text { Gede Bage }\end{array}$ & $\begin{array}{l}\text { GM1 } \\
\text { GM2 } \\
\text { GM3 } \\
\text { GM4 } \\
\end{array}$ & $\begin{array}{l}\text { Negatif } \\
\text { Negatif } \\
\text { Negatif } \\
\text { Negatif }\end{array}$ & $\begin{array}{l}\text { Crystal Panceau } \\
\text { Crystal Panceau } \\
\text { Crystal Panceau } \\
\text { Amaranth }\end{array}$ \\
\hline 2. & $\begin{array}{l}\text { Pasar } \\
\text { Induk } \\
\text { Caringin }\end{array}$ & $\begin{array}{l}\text { CM1 } \\
\text { CM2 } \\
\text { CM3 } \\
\text { CM4 } \\
\text { CM5 } \\
\text { CM6 } \\
\text { CM7 } \\
\text { CM8 } \\
\text { CM9 } \\
\end{array}$ & $\begin{array}{l}\text { Negatif } \\
\text { Negatif } \\
\text { Negatif } \\
\text { Negatif } \\
\text { Negatif } \\
\text { Negatif } \\
\text { Negatif } \\
\text { Negatif } \\
\text { Negatif }\end{array}$ & $\begin{array}{l}\text { Crystal Panceau } \\
\text { Crystal Panceau } \\
\text { Crystal Panceau } \\
\text { Crystal Panceau } \\
\text { Crystal Panceau } \\
\text { Crystal Panceau } \\
- \\
\text { Crystal Panceau } \\
\text { Azorubin A }\end{array}$ \\
\hline
\end{tabular}

Hasil analisis kualitatif rhodamin B dengan metode spot test menunjukkan seluruh sampel yang diuji menggunakan pewarna sintetis karena terdapat warna yang tertinggal pada wol sebagai instrumen analisis. Kemudian saat dilakukan analisis lebih lanjut dengan mereaksikan wol dengan larutan pereaksi, seluruh produk dinyatakan $100 \%$ negatif mengandung pewarna berbahaya rhodamin $\mathrm{B}$, melainkan teridentifikasi sebagai produk yang menggunakan pewarna sintetis jenis lain. Maka dari itu tidak dilakukan pengujian secara kuantitatif pada sampel.

Mekanisme dari pengujian kualitatif dengan metode spot test adalah sebagai berikut : mula-mula sampel akan terhidrolisis oleh HCL 6N yang ditambahkan pada saat proses pemanasan, kemudian zat pewarna yang terkandung dalam sampel akan melekat pada wol, yang dapat dikatakan bahwa pewarna tersebut merupakan pewarna sintetis. Setelah proses pencucian wol yang telah terwarnai akan dibagi menjadi empat bagian dan masing-masing diberikan larutan pereaksi berupa $\mathrm{HCL}$ pekat, $\mathrm{H}_{2} \mathrm{SO}_{4}$ pekat, $\mathrm{NaOH} 30 \%$, dan $\mathrm{NH}_{4} \mathrm{OH} 10 \%$. Jika sampel positif mengandung rhodamin B, maka wol akan mengalami perubahan warna menjadi jingga dengan penambahan HCL pekat, kuning dengan penambahan $\mathrm{H}_{2} \mathrm{SO}_{4}$ pekat, biru dengan penambahan $\mathrm{NaOH} 30 \%$, dan biru dengan penambahan $\mathrm{NH}_{4} \mathrm{OH} 10 \%$. Namun, dari hasil pengujian yang telah dilakukan, wol menunjukan perubahan warna yang lain.

Hasil pengujian menunjukan bahwa terdapat jenis pewarna sintetis selain rhodamin B yang diduga terkandung dalam sampel, diantaranya crystal panceau, amaranth dan azorubin A. Menurut PERMENKES RI NOMOR 033 TAHUN 2012, azorubin A atau karmoisin termasuk sebagai pewarna sintetis yang diperbolehkan. Sedangkan crystal panceau menurut Imansari (2018) merupakan bentuk kristal dari ponceau 6 yang dilarang penggunaannya menurut PERMENKES RI NOMOR 239/Men.Kes/Per/V/85. Kemudian pada jenis pewarna amaranth, tidak tercantum dalam kategori zat pewarna sitetis yang diperbolehkan maupun dilarang menurut peraturan menteri kesehatan.

Sampel yang teridentifikasi sebagai produk yang mengandung pewarna crystal panceau sebanyak 8 sampel sagu mutiara kering dengan kode GM1, GM2, GM3, CM1, CM2, CM3, CM4 dan CM5, serta dua sampel pada produk sagu mutiara basah dengan kode sampel CM6 dan CM8. Kemudian pada sampel yang teridentifikasi mengandung pewarna amaranth dan azorubin A masing-masing sebanyak satu sampel pada produk sagu mutiara basah, dengan kode sampel berturut-turut GM4 dan CM9. Sedangkan sampel dengan kode CM7 tidak teridentifikasi jenis pewarnanya.

Sampel yang teridentifikasi sebagai produk yang mengandung pewarna crystal panceau pada saat pengujian mengalami perubahan warna menjadi merah dengan penambahan HCL pekat, violet dengan penambahan $\mathrm{H}_{2} \mathrm{SO}_{4}$ pekat, coklat pudar dengan 
penambahan $\mathrm{NaOH} 30 \%$, dan sedikit perubahan dengan penambahan $\mathrm{NH}_{4} \mathrm{OH} 10 \%$.

Crystal panceau yang merupakan bentuk kristal dari ponceau 6R pewarna azo merah yang banyak digunakan sebagai pewarna makanan dan juga digunakan dalam pewarnaan histologi. Pewarna ini memiliki rumus molekul $\mathrm{C}_{20} \mathrm{H}_{12} \mathrm{~N}_{2} \mathrm{Na}_{2} \mathrm{O}_{7} \mathrm{~S}_{2}$, sifatnya larut dalam air dan sedikit larut dalam etanol. Jenis pewarna ini dilarang penggunaannya di Indonesia karena dapat menimbulkan masalah kesehatan.

Penelitian mengenai ponceau 6R telah dilakukan dimana beberapa babi diberikan makanan yang mengandung ponceau $6 \mathrm{R}$ dengan dosis $0,100,500$, dan $1500 \mathrm{mg} / \mathrm{kg}$ bb/hari selama 102-105 hari. Hasil penelitian menunjukkan pada kelompok $1500 \mathrm{mg}$ terlihat penurunan berat badan dan pemanfaatan makanan, serta 1 babi mati dengan anemia hemolitik (Hansen, 2004).

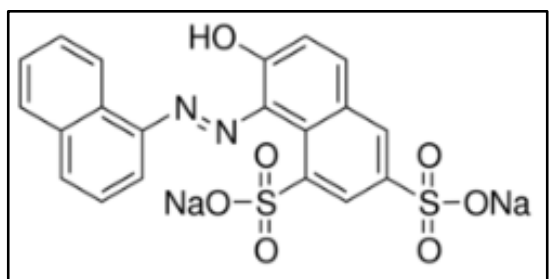

Gambar 1. Struktur Cyrstal Panceau (Aldrich, 2019)

Sampel yang teridentifikasi sebagai produk yang mengandung pewarna amaranth pada saat pengujian mengalami perubahan warna menjadi merah keunguan dengan penambahan HCL pekat, lebih gelap dengan penambahan $\mathrm{H}_{2} \mathrm{SO}_{4}$ pekat, ungu kecoklatan dengan penambahan $\mathrm{NaOH} 30 \%$, dan sedikit perubahan dengan penambahan $\mathrm{NH}_{4} \mathrm{OH} 10 \%$.

Amaranth merupakan pewarna merah tua ke ungu dan memiliki rumus moekul $\mathrm{C}_{20} \mathrm{H}_{11} \mathrm{~N}_{2} \mathrm{Na}_{3} \mathrm{O}_{10} \mathrm{~S}_{3}$, pewarna ini pernah digunakan sebagai pewarna pangan dan kosmetik namun sejak tahun 1976 telah dilarang penggunaannya oleh Food and Drug Administration (FDA) karena diduga merupakan zat karsinogen atau penyebab kanker (Prabawandwika, 2011).

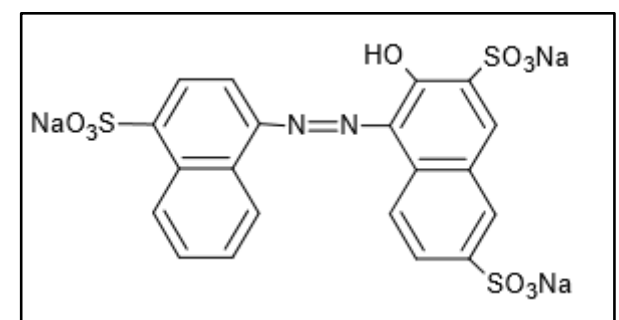

Gambar 2. Struktur Amaranth (Sumarlin, 2010)

Pewarna Amaranth (Food Red No.2) dalam jumlah besar akan menimbulkan tumor, reaksi alergi dan pernafasan, serta dapat menyebabkan asma serta meyebabkan hiperaktif pada anak-anak (Susilawati,2018).

Sampel yang teridentifikasi sebagai produk yang mengandung pewarna karmoisin atau azorubin A pada saat pengujian mengalami perubahan warna menjadi sedikit berubah dengan penambahan HCL pekat, violet dengan penambahan $\mathrm{H}_{2} \mathrm{SO}_{4}$ pekat, merah dengan penambahan $\mathrm{NaOH} 30 \%$, dan merah dengan penambahan $\mathrm{NH}_{4} \mathrm{OH} 10 \%$.

Karmoisin adalah perwarna sintetis yang mengandung struktur azo dan cincin aromatik dan sering digunakan pada pewarnaan pangan, minuman, obat-obatan, dan kosmetika (Sumarlin, 2010).

Azorubin A atau karmoisin menurut Karunia (2013) merupakan pewarna makanan sintetis yang memberikan warna merah segar pada makanan dan minuman. Karmoisin tidak boleh dikonsumsi secara berlebihan, karena dapat menyebabkan alergi pada kulit dan mengaktifkan sel-sel kanker dalam tubuh. Batasan penggunaan yang tidak menimbulkan bahaya jika dikonsumsi manusia yaitu $50-300$ mg batas PERMENKES RI per kg makanan, dan $0-4 \mathrm{mg}$ batas ADI per kg berat badan.

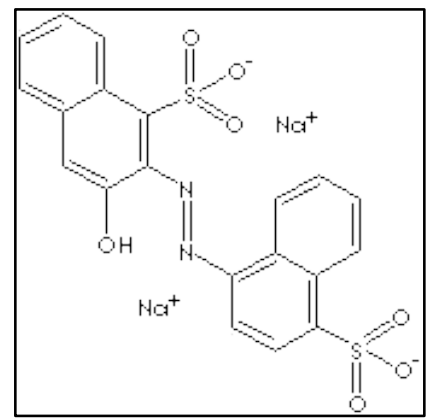

Gambar 3. Struktur Azorubin A (Prabawandwika, 2011)

Penelitian ini memberikan informasi bahwa kini penggunaan zat pewarna berbahaya rhodamin B sudah tidak marak lagi digunakan berkat adanya kesadaran dari produsen. Namun ada indikasi bahwa produsen mencari alternatif lain untuk mensiasati rhodamin B dengan fungsi maupun kualitas yang sama, tapi tetap dapat menekan biaya produksi. Penggunaan pewarna sendiri bagi produsen cukup penting untuk menarik perhatian konsumen terhadap produknya. Pewarna dapat meningkatkan mutu makanan dari segi penampilannya.

Bahaya rhodamin B sendiri terhadap kesehatan manusia menurut BPOM (2008) antara lain menyebabkan iritasi saluran pernafasan, kulit, mata, dan saluran pencernaan yang berefek racun jika tertelan.

Menurut Masthura (2019), di dalam rhodamin B terdapat ikatan dengan klorin $(\mathrm{Cl})$, dimana senyawa klorin ini merupakan senyawa anorganik yang reaktif dan juga berbahaya. Rekasi yang mengikat ion klorin disebut sebagai sintesis zat warna. Disini dapat digunakan Reaksi Frield- Crafts untuk mensintesis zat warna seperti triarilmetana dan xentana. Rekasi antara ftalat anhidrida dan resorsinol dengan keberadaan seng klorida menghasilkan fluoresein. Apabila resorsinol diganti dengan $\mathrm{N}-\mathrm{N}$ - dietilaminofenol, reaksi ini akan menghasilkan rhodamin B. Selain terdapat ikatan rhodamin B dengan Klorin, terdapat juga ikatan konjugasi. Ikatan konjugasi dari rhodamin B inilah yang 
menyebabkan rhodamin B bewarna merah. Ditemukannya bahaya yang sama antara rhodamin B dan Klorin membuat adanya kesimpulan bahwa atom Klorin yang ada pada rhodamin B adalah penyebab terjadinya efek toksik bila masuk ke dalam tubuh manusia. Atom $\mathrm{Cl}$ itu sendiri merupakan golongan halogen, dimana halogen dalam senyawa organik bersifat toksik dan karsinogenik.

Ciri-ciri produk pangan yang mengandung pewarna rhodamin B menurut Febriani (2018) antara lain : warnanya merah cerah dan mencolok, warnanya tidak homogen (ada yang menggumpal), ada sedikit rasa pahit dan muncul rasa gatal di tenggorokan setelah mengonsumsinya.

Hasil wawancara dengan 6 pedagang yang tersebar di Kota Bandung selaku konsumen yang menggunakan produk sagu mutiara, semua menyatakan bahwa produk sagu mutiara yang mereka dapatkan berasal dari pasar terdekat dari tempatnya berjualan, sehingga ada indikasi bahwa pasar-pasar tersebut dipasok dari Pasar Induk yang ada di Kota Bandung, yaitu Pasar Induk Gede Bage ataupun Pasar Induk Caringin, tergantung mana yang lebih dekat.

Pedagang es goyobod di Buah Batu, pedagang es campur di jalan Banteng, dan pedagang sekoteng di Cibiru, masing-masing mendapatkan produk sagu mutiara dari Pasar Kosambi, Pasar Kordon, dan Pasar Ujung Berung yang kemungkinan dipasok dari Pasar Induk Gede Bage. Sedangkan pada pedagang es campur di Ciumbuleuit, pedagang es shanghai di Dago, dan pedagang bubur lemu di Astana Anyar, masing-masing mendapatkan produk sagu mutiara dari Pasar Sederhana, Pasar Simpang Dago, dan Pasar Astana Anyar yang kemungkinan dipasok dari Pasar Induk Caringin.

Wawancara dengan pedagang pasar induk yang menjual produk sagu mutiara memberikan informasi seluruh pedagang mengaku mendapatkan pasokan barang dagangannya dari grosir produsen sagu mutiara maupun sales. Dari 12 pedagang sagu mutiara, 2 orang yang mengetahui tentang pewarna berbahaya rhodamin B atau wantex dan 2 orang lainnya mengetahui tentang peredaran makanan dengan bahan pewarna berbahaya, sedangkan 8 orang lainya tidak mengetahui sama sekali tentang bahan pewarna berbahaya serta peredarannya.

Pemaparan hasil wawancara di atas menunjukkan bahwa pengetahuan pedagang tentang penggunaan bahan pewarna berbahaya pada makanan masih minim, hal ini dapat dipicu dari tingkat pendidikan atau yang paling penting adalah dari tingkat kepedulian para pedagang terhadap masalah ini. Jika dilihat profil para pedagang di pasar induk, semua menyatakan telah memulai usahanya dari bertahun-tahun lalu, sehingga dapat dikatakan bahwa para pedagang memiliki cukup pengalaman terkait barang dagangannya, dimana barang yang dijual merupakan barang yang biasanya laku dan dapat mendatangkan keuntungan bagi para pedagang. Maka dari itu, peredaran makanan dengan bahan pewarna berbahaya di masyarakat ini erat kaitannya dengan pihak produsen yang memasok barang dagangannya dikalangan pedagang.

Masyarakat berhak mendapatkan perlindungan dari kemungkinan terburuk mengalami resiko kesehatan akibat makanan yang beredar, sehingga pemerintah perlu lebih banyak lagi melakukan sosialisasi maupun sidak terhadap peredaran makanan dengan pewarna berbahaya. Selain itu, perlu ketegasan hukum dalam menerapkan pasal 75 ayat (1) Undang-undang Nomor 18 Tahun 2012 tentang pangan, kepada produsen yang memproduksi pangan dengan menggunakan bahan berbahaya.

Berdasarkan hasil penelitian mengenai identifikasi rhodamin B pada sagu mutiara di Pasar Induk Kota Bandung dapat disimpulkan bahwa asil analisis secara kualitatif zat pewarna dengan metode spot test pada 13 sampel dinyatakan $100 \%$ negatif mengandung rhodamin $\mathrm{B}$, namun teridentifikasi pewarna jenis lain yaitu crystal panceau, amaranth dan azorubin $\mathrm{A}$.

\section{Daftar Pustaka}

1. Andayani, Dahlia dan Adisaputra, Hardiono. 2013. Analisis Zat Pewarna Rhodamin B pada Gula Kapas Merah yang Dijual di Kota Mataram Tahun 2013. Jurnal Ilmu Farmasi. 1(1): 1.

2. Augustyn. 2007. Karakterisasi Beberapa Sifat Pati Ubi Kayu (Manihot esculenta, Crantz). Jurnal Teknologi Hasil Pertanian. 3(51): 35.

3. Badan POM RI. 2013. Peraturan kepala BPOM RI nomor 37 Tahun 2013 tetang Batas Maksimum Penggunaan Bahan Tambahan Pangan Pewarna. Jakarta: Kepala Badan Pengawas Obat dan Makanan Republik Indonesia.

4. Badan POM RI. 2015. Informasi Pengamanan Bahan Berbahaya Rhodamin B. Jakarta: Badan Pengawas Obat dan Makanan Republik Indonesia.

5. Bungin, Burhan. 2005. Metodologi Penelitian Kuantitatif. Jakarta: Kencana.

6. Departemen Kesehatan Republik Indonesia. 1985. Permenkes RI No. 239/Menkes/Per/V/1985. Jakarta: Departemen Kesehatan Republik Indonesia.

7. Departemen Kesehatan Republik Indonesia. 1995. Daftar Komposisi Zat Gizi Pangan Indonesia. Jakarta: Departemen Kesehatan Republik Indonesia.

8. Departemen Kesehatan Republik Indonesia. 2012. Permenkes RI nomor 033 Tahun 2012. Jakarta: Departemen Kesehatan Republik Indonesia.

9. Elida, Septina dan Vaulina, Sisca. 2018. Peran Keanekaragaman Hayati untuk Mendukung Indonesia sebagai Lumbung Pangan Dunia. Seminar Nasional. 2(1): 121.

10. Febriani. 2018. Gambaran Konsumsi Pangan Jajan Anak Sekolah (PJAS) yang Mengandung Rhodamin $B$ pada Murid SD di Kecamatan Bogor Barat 
Tahun 2018. Laporan Penelitian RISBINKES, hlm 7-23.

11. Hansen, E.V. 2004. A Short Term Peroral Study Of The Food Colour, Ponceau 6R In Pigs. Toxycology. 10(4): 363-368.

12. Imansari. 2018. Higiene Sanitasi Dan Kandungan Pewarna Berbahaya Pada Keripik Pisang. hlm 1 9.

13. Masthura. 2019. Identifikasi Rhodamin B dan Methanyl Yellow pada Manisan Buah yang Beredar di Kota Banda Aceh Secara Kualitataif. Jurnal Kimia. 1(1): 42.

14. Nur'aini, Hesti dan Apriyani, Siska. 2015. Penggunaan Kitosan untuk Memperpanjang Umur Simpan Buah Duku. Jurnal Agritepa. 1(2): 200.

15. Nurrohmah, Dyah Eka. 2018. Analisis Kandungan Pewarna Alami dan Sintetis pada Jajanan yang dijual di Pasar Gede Surakarta. Skripsi Ilmu Kesehatan, hlm. 9.

16. Prabawandwika s. 2011. Amaranth. Artikel Teknologi Hasil Pertanian, hlm. 1.

17. Sudjana. 2001. Metode \& Teknik Pembelajaran Partisipatif. Bandung : Falah Production.

18. Sujarweni, V. Wiratna. 2014. Metodologi Penelitian. Yogyakarta: Pustaka Baru.

19. Susilawati. 2018. Analisis Tigkat Pengetahuan Pedagang dalam Penggunaan Kandungan Zat Pewarna Merah pada Bubuk Cabai dalam Makanan Jajanan di Kelurahan Tembung Kecamatan Medan Tembung Tahun 2018. Jurnal Kesehatan Masyarakat. 3(4): 4.

20. Tjiptaningdyah, Restu dan Sucahyo,Sigit Bambang. 2017. Analisis Zat Pewarna Rhodamin-B Pada Jajanan yang Dipasarkan di Lingkungan Sekolah. Penelitian DIPA, hlm 10.

21. Undang-Undang RI Nomor 18 Tahun 2012 tentang Pangan.

22. Widaningsih, Roch. 2016. Outlook Ubi Kayu. Pusat Data dan Sistem Informasi Pertanian Kementerian Pertanian 2016. 